\title{
Molecular Biogeography of Tribe Thermopsideae (Leguminosae): A Madrean-Tethyan Disjunction Pattern with an African Origin of Core Genistoides
}

\author{
Ming-Li Zhang, ${ }^{1,2}$ Jian-Feng Huang, ${ }^{1,3}$ Stewart C. Sanderson, ${ }^{4}$ \\ Ping Yan, ${ }^{5}$ Yu-Hu Wu, ${ }^{6}$ and Bo-Rong Pan ${ }^{1}$ \\ ${ }^{1}$ Key Laboratory of Biogeography and Bioresource in Arid Land, Xinjiang Institute of Ecology and Geography, \\ Chinese Academy of Sciences, Urumqi, Xinjiang 830011, China \\ ${ }^{2}$ Institute of Botany, Chinese Academy of Sciences, Beijing 100093, China \\ ${ }^{3}$ Xishuangbanna Tropical Botanical Garden, Chinese Academy of Sciences, Kunming, Yunnan 650223, China \\ ${ }^{4}$ Shrub Sciences Laboratory, Intermountain Research Station, Forest Service, U.S. Department of Agriculture, UT 84601, USA \\ ${ }^{5}$ School of Life Science, Shihezi University, Shihezi, Xinjiang 832003, China \\ ${ }^{6}$ Northwest Plateau Institute of Biology, Chinese Academy of Sciences, Xining, Qinghai 810001, China
}

Correspondence should be addressed to Ming-Li Zhang; zhangml@ibcas.ac.cn and Bo-Rong Pan; brpan@ms.xjb.ac.cn

Received 9 September 2014; Revised 20 December 2014; Accepted 8 January 2015

Academic Editor: Peter F. Stadler

Copyright (c) 2015 Ming-Li Zhang et al. This is an open access article distributed under the Creative Commons Attribution License, which permits unrestricted use, distribution, and reproduction in any medium, provided the original work is properly cited.

Thermopsideae has 45 species and exhibits a series of interesting biogeographical distribution patterns, such as Madrean-Tethyan disjunction and East Asia-North America disjunction, with a center of endemism in the Qinghai-Xizang Plateau (QTP) and Central Asia. Phylogenetic analysis in this paper employed maximum likelihood using ITS, $r p s 16, p s b \mathrm{~A}-\operatorname{tr} n \mathrm{H}$, and $\operatorname{trn} \mathrm{L}-\mathrm{F}$ sequence data; biogeographical approaches included BEAST molecular dating and Bayesian dispersal and vicariance analysis (S-DIVA). The results indicate that the core genistoides most likely originated in Africa during the Eocene to Oligocene, ca. 55-30 Ma, and dispersed eastward to Central Asia at ca. 33.47 Ma. The origin of Thermopsideae is inferred as Central Asian and dated to ca. $28.81 \mathrm{Ma}$. Ammopiptanthus is revealed to be a relic. Birth of the ancestor of Thermopsideae coincided with shrinkage of the Paratethys Sea at ca. $30 \mathrm{Ma}$ in the Oligocene. The Himalayan motion of QTP uplift of ca. $20 \mathrm{Ma}$ most likely drove the diversification between Central Asia and North America. Divergences in East Asia, Central Asia, the Mediterranean, and so forth, within Eurasia, except for Ammopiptanthus, are shown to be dispersals from the QTP. The onset of adaptive radiation at the center of the tribe, with diversification of most species in Thermopsis and Piptanthus at ca. 4-0.85 Ma in Tibet and adjacent regions, seems to have resulted from intense northern QTP uplift during the latter Miocene to Pleistocene.

\section{Introduction}

In the Leguminosae, the so-called core genistoides includes tribes Crotalarieae, Genisteae, Podalyrieae, Thermopsideae, Euchresteae, and Sophoreae sensu strictu [1-8]. Tribe Thermopsideae includes seven genera and about (43)-45-(46) species and occurs in the temperate regions of Eurasia and North America [6, 9]. Of them, Pickeringia, with one species endemic to western North America, has been transformed into Cladrastis-Styphnolobium $[5,10]$. Thermopsis and Baptisia are two perennial herbaceous genera, respectively, in distributions of an East Asian-North American disjunction and North American endemism. Anagyris, Piptanthus, and Ammopiptanthus are shrubby and in Eurasia. Anagyris includes two species and occurs around the Mediterranean Basin [11, 12]. Piptanthus and Ammopiptanthus mainly occur in China, the former in Sino-Himalayan [13] and the latter in Central Asian regions [14]. New monotypic genus Vuralia recently is segregated from Thermopsis in Turkey [15].

Molecular evidence above the rank of genus has provided a foundation for Thermopsideae systematics and biogeography $[4,5,16-19]$. However, due to a lack of sufficient 
species sampling, a dense addition of species at generic level is necessary. Wang et al. [14] carried out a comprehensive systematic study of Thermopsideae on the basis of dense species addition and ITS sequences. Biogeographically, the fossil record indicates that the three legume subfamilies appeared in the early Eocene, and extensive diversification and origin of most of the woody legume lineages occurred in the middle Eocene [20]. Schrire et al. [21] divided the distribution patterns of ca. 730 legume genera into four biomes, that is, succulent, grass, rainforest, and temperate, with temperate groups possessing the largest numbers. From macrofossils of leaves and pods, the origin of legumes appears unlikely to have been much before $60 \mathrm{Ma}$, and, from that time, a rapid diversification among major clades took place [22]. In contrast with a proposed West Gondwana origin of the family $[23,24]$ or a "moist equatorial megathermal" origin, recent studies favor an origin in the seasonally dry to arid tropical Tethyan seaway corridor [21]. Lavin et al. [22] established a comprehensive schematic chronogram of legumes based on sequence data and fossil constraint, employing a total of 324 species. However, only three species of Thermopsideae were sampled. Lavin et al. [22] estimated ca. 26.5 Ma for the time of origin of Thermopsideae, and Ortega-Olivencia and Catalán [12] dated the appearance of Anagyris to late Miocene $(8.2 \pm 4.5 \mathrm{Ma})$. Xie and Yang [25] estimated Ammopiptanthus to have originated in early Miocene ca. 20-21 Ma.

Exceptionally, in the Wang et al. [14] study, although there was strong support for the tribal clade, the systematic position of Ammopiptanthus was suspected as not being a member of Thermopsideae because of the nesting of three Sophora species with it, resulting in Ammopiptanthus being placed in a basally branching position with respect to the rest of the tribe. Many studies have speculated that Piptanthus, Ammopiptanthus, Thermopsis, and so forth in the tribe originated in the Tertiary [14, 26-29], but the exact time and place of origin have remained poorly understood.

In summary, Thermopsideae contains many attractive biogeographical topics, Central Asia, East Asia, and QTP endemism and Madrean-Tethyan disjunction, East AsiaNorth America disjunction, Tertiary origin, and so forth. Therefore, this paper attempts to reconstruct the phylogeny of the tribe using four genes and, afterward, focuses on the tribe Thermopsideae biogeography by employing biogeographical molecular dating and S-DIVA approaches to explore the spatiotemporal origin and evolution of Thermopsideae and its evolutionary dynamics; to confirm the Madrean-Tethyan disjunction using Thermopsideae; and to discuss the East Asia-North America disjunction, Central Asian endemism, QTP endemism, and so forth.

\section{Materials and Methods}

2.1. Taxon Sampling. We sampled 32 individuals of 20 species, mainly from China, belonging to three genera, Thermopsis, Piptanthus, and Ammopiptanthus of Thermopsideae; see Table 1. Outgroups were selected from Sophora (S. davidii, S. flavescens, and S. microphylla), Podalyria (Podalyrieae), and Cytisus (Genisteae); see Supplementary Material S 1 available online at http://dx.doi.org/10.1155/2015/864804. More outgroup species were used in ITS phylogeny; also see S 2 .

2.2. DNA Sequencing. Total genomic DNA was extracted using the CTAB method [30]. The polymerase chain reaction (PCR) was used for amplification of double stranded DNA. A $25 \mu \mathrm{L}$ reaction system contained $0.25 \mu \mathrm{L}$ of Ex Taq, $2.5 \mu \mathrm{L}$ of $10 \times$ Ex Taq buffer $\left(\mathrm{Mg}^{2+}\right.$ concentration of $\left.25 \mathrm{mM}\right), 2.0 \mu \mathrm{L}$ of dNTP mix ( $2.5 \mathrm{mM}$ concentration for each dNTP), $1 \mu \mathrm{L}$ of the forward and reverse primers at $5 \mu \mathrm{mol} / \mu \mathrm{L}$, and $0.5 \mu \mathrm{L}$ of template DNA. The following primers were used: for ITS, ITS1-F (5'-AGA AGT CGT AAC AAG GTT TCC GTA GC$\left.3^{\prime}\right)$ and ITS4-R ( $5^{\prime}$-TCC TCC GCT TAT TGA TAT GC- $\left.3^{\prime}\right)$ [31], for trnL-F, trnLF ( $5^{\prime}$-CGA AAT CGG TAG ACG CTA CG- $\left.3^{\prime}\right)$ and trnFR ( $5^{\prime}$-ATT TGA ACT GGT GAC ACG AG$\left.3^{\prime}\right)$ [32], for $p s b \mathrm{~A}-\mathrm{trn} \mathrm{H}, \mathrm{ps} b \mathrm{AF}\left(5^{\prime}\right.$-GTT ATG CAT GAA CGT AAT GCT C- $\left.3^{\prime}\right)$ [33] and $t r n \mathrm{HR}\left(5^{\prime}\right.$-CGC GCA TGG ATT CAC AAT CC- $3^{\prime}$ ) [34], and, for the intron of rps16, rps16F ( $5^{\prime}$-GTG GTA GAA AGC AAC GTG CGA CTT- ${ }^{\prime}$ ), and for rps16R ( $5^{\prime}$-TCG GGA TCG AAC ATC AAT TGC AAC- $\left.3^{\prime}\right)$ [35].

PCR amplifications were carried out using the following procedures: there was predenaturation at $94^{\circ} \mathrm{C}$ for $3 \mathrm{~min}$., followed by 30 cycles of (1) denaturation at $94^{\circ} \mathrm{C}$ for $30 \mathrm{~s}$, (2) annealing at $48^{\circ} \mathrm{C}-54^{\circ} \mathrm{C}$ for $30 \mathrm{~s}$, and (3) extension at $72^{\circ} \mathrm{C}$ for $1 \mathrm{~min}$.; at the end of these cycles, there was a final extension at $72^{\circ} \mathrm{C}$ for $10 \mathrm{~min}$. PCR products were purified using the $\mathrm{PEG}$ precipitation procedure [36]. Sequencing reactions were performed by a company specializing in the procedure (Beijing Sanbo Biological Engineering Technology and Service Corporation, China). Sequences were aligned using CLUSTAL X software [37] and then adjusted by hand in BioEdit ver. 5.0.9 [38].

2.3. Phylogenetic Analyses. Two datasets consisting of ITS and the 4-gene sequences combined (ITS $+3 \mathrm{cpDNA}$ ) were prepared for phylogenetic analysis. The 4-gene dataset was examined using the incongruence length difference (ILD) tests [39], implemented in PAUP version 4.0b10 [40], with 100 homogeneity replicates, 10 random addition sequences, treebisection-reconnection (TBR) branch swapping on best only, and MULTREES on, and this was performed to test whether the four datasets could be combined. The data partitions of four genes were not significantly incongruent on the basis of the ILD tests $(P=0.01)$.

Phylogenetic analysis by Maximum Likelihood (ML) of the 4-gene combined sequences was conducted using PAUP* $4.0 \mathrm{~b} 10$ [40].

For ML analysis, the best fitting DNA substitution model was found employing Modeltest 3.6 [41], of which the Akaike information criterion (AIC) was selected on the basis of the log likelihood scores of 56 models [41]. For the dataset, the $\operatorname{TrN}+\mathrm{G}$ model was selected as the most appropriate in Modeltest 3.5, with the nucleotide frequencies $\mathrm{A}=0.3283$, $\mathrm{C}=0.1676, \mathrm{G}=0.1985, \mathrm{~T}=0.3055$, the shape parameter $=$ 0.6264 , and an assumed proportion of invariable (PIV) sites $=0$. Clade support for the phylogenetic tree was estimated, 


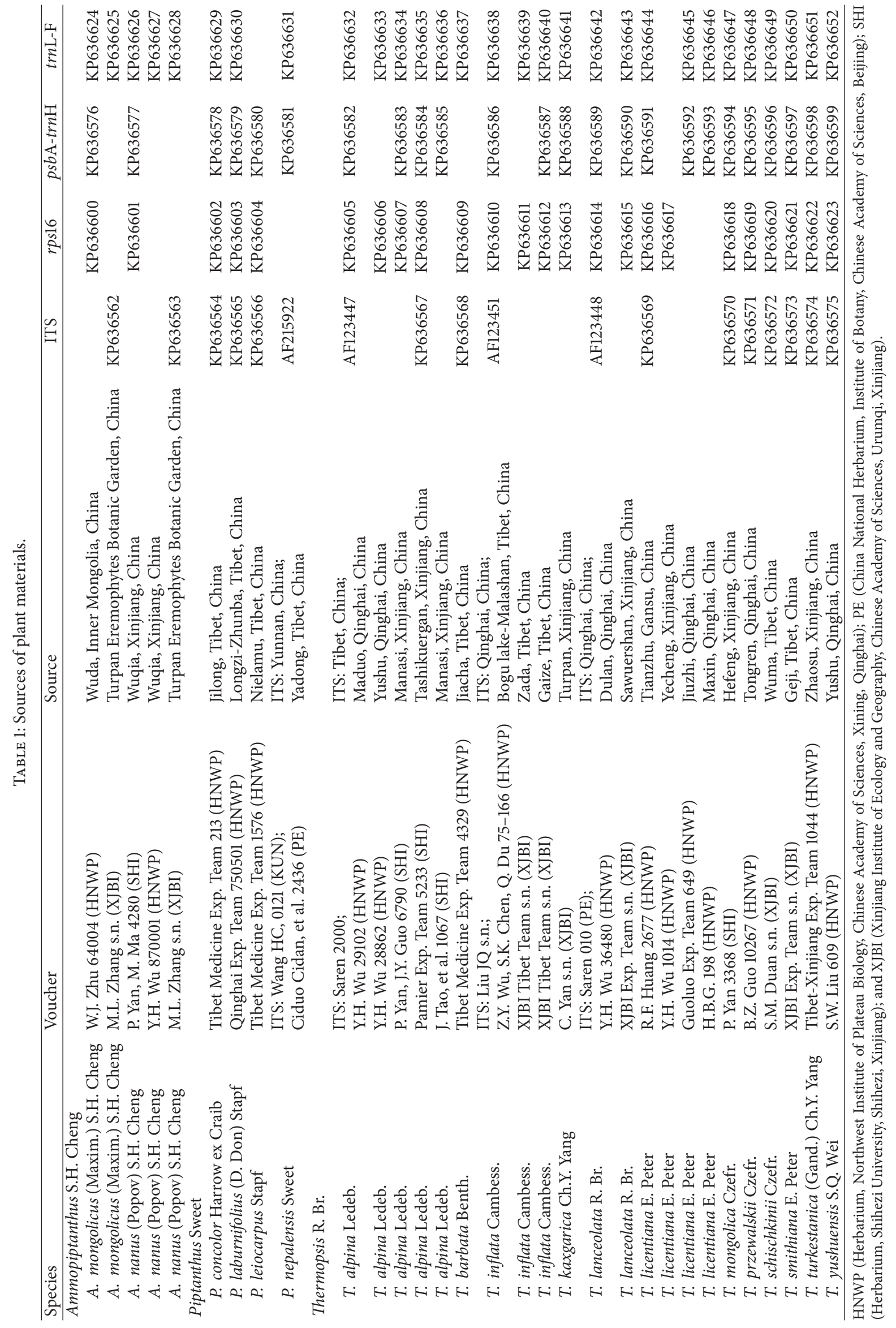


TABLE 2: References for fossils of seven genera used to constrain ages for dating.

\begin{tabular}{lccc}
\hline Taxa & Time (Ma) & Location & Reference \\
\hline Cercis & 60-11 Late Cretaceous-Miocene & China & Tao, 1992 [58]; Tao et al., 2000 [42] \\
Cercis & Eocene & N America & Lavin et al., 2005 [22] \\
Acacia & $47-42$ Eocene & Liaoning, China; Tanzania & Tao et al., 2000 [42]; Lavin et al., 2005 [22] \\
Acacia & 15 Miocene & Dominican Rep. & Lavin et al., 2005 [22] \\
Bauhinia & ca. 65 later Cretaceous & Helongjiang, China, & Tao et al., 2000 [42] \\
Cladrastis & $40-20$ middle Eocene & Tennessee, N America & Herendeen et al., 1992 [20] \\
Cladrastis & Miocene & Inner Mongolia & Tao et al., 2000 [42] \\
Sophora & 35-9 Oligocene-Miocene & China, Siberia, N America & Tao et al., 2000 [42]; IB \& NIGP, 1978 [43] \\
Pueraria & $17-5$ Miocene & Yunnan, Shandong, China & Tao, 1992 [58]; Tao et al., 2000 [42] \\
Dalbergia & $19.5-5$ Miocene & China, N America, Europe & IB \& NIGP, 1978 [43]; Tao, 1992 [58]; Tao et al., 2000 [42] \\
\hline
\end{tabular}

IB and NIGP: Institute of Botany and Nanjing Institute of Geology and Palaeontology, Academia Sinica.

employing bootstrap values in PAUP and posterior probability values in MrBayes software.

In order to obtain comprehensive molecular dating, ITS sequence data covered broad outgroups including the four core genistoides tribes and seven fossil genera, which came from our data and from GenBank; see S 2. The final dataset comprised 107 species and 722 bps.

\subsection{Estimating Divergence Times}

2.4.1. Fossil Constraints. Legumes have rich fossil records $[20,42]$, but there are fewer fossils assignable to the core genistoides and Thermopsideae. Most fossils of legume genera date to the Miocene, with several approaching the Eocene and Paleocene, with Bauhinia and Cercis extending even to the Late Cretaceous $[42,43]$. Seven fossil genera are used as outgroups; see Table 2. The occurrence of Sophora in the Oligocene-Miocene is credible, since its fossils are known from the Eocene of eastern Siberia and North America $[42,43]$. In China, Sophora fossils have been found in Oligocene strata from Heilongjiang province, the Miocene from Shandong and Yunnan provinces, and Pliocene from Shanxi province $[42,43]$. Acacia in the Eocene is also well represented in museum collections. Dalbergia fossils, including leaves and fruit, have been recorded at the Eocene-Miocene boundary in North America, the Oligocene-Miocene boundary in Europe, and in the Miocene in Yunnan Province, China. Fossil leaves of Pueraria appeared in the Miocene in Shandong and Yunnan provinces, China $[42,43]$, and Cladrastis has been dated to middle Eocene [22].

In terms of the ancient fossil record and the phylogenetic tree, the root taxon was considered as Cercis. In the southern China Guangdong province, Cercis fossils haves been found from the Late Cretaceous to Eocene, in the Oligocene of Yunnan province, and the Miocene of Shandong and Qinghai provinces. Therefore, this genus is regarded as the root taxon and the age of its ancestor is constrained as $60 \mathrm{Ma}$. This root constraint is in agreement with Lavin et al. [22], by whom the ancestor of Polygala and Cercis was constrained at $60 \mathrm{Ma}$. Detailed information are described in Table 2.

The outgroup fossil dates were used as the constraint minimum ages; that is, the maximum fossil dates were selected as the generic minimum age of the most recent common ancestor (MRCA).

2.4.2. Dating Implementation. Currently, phylogenetic dating approaches include r8s, PAML, and BEAST. Of them, BEAST has an advantage for practical applications because of its nondependence on a phylogenetic tree, and convenient implementation software (BEAST vl.46, http://beast.bio.ed.ac.uk). Moreover, a relaxed molecular clock and Bayesian MCMC search optima are available within it $[44,45]$.

BEAST was implemented [46] using a Yule process speciation prior to an uncorrelated lognormal model of rate variation and a normal distribution. Tracer vl.4 was used to measure the effective sample size of each parameter and mean and $95 \%$ credibility intervals. Two separate MCMC analyses were run for 20,000,000 generations and sampled every 1000 generations. After discarding as burn-in the first $10 \%$ of trees searched, the mean and $95 \%$ credibility intervals of MRCA nodes were calculated by TreeAnnotator v1.4.8. and visualized by FigTree v.1.2.4 [46].

2.5. Biogeographic S-DIVA. DIVA is used to infer mainly ancestral distributions and biogeographical events [47]; it is an event-based method that optimizes ancestral distributions by assuming a vicariance explanation, while incorporating the potential contributions of dispersal and extinction, despite minimizing these under a parsimony criterion $[47$, 48]. Nylander et al. [49] proposed a modified approach to DIVA naming it Bayes-DIVA because it integrates biogeographical reconstructions of DIVA over the posterior distribution of a Bayesian MCMC sample of tree topologies. Bayes-DIVA is also referred to as S-DIVA [50].

The BEAST dating tree (Figure 2) was treated as a fully resolved phylogram for use as a basis for S-DIVA, and 791 post burnin trees derived from the BEAST analysis were used for ancestral area reconstruction in the program S-DIVA beta version 1.9. S-DIVA was performed with constraints of maximum areas 2 at each node, to infer possible ancestral areas and potential vicariance and dispersal events.

Geographic areas were chosen to cover the distributions of the four core genistoides tribes, especially tribe Thermopsideae. Seven geographic endemic areas were defined in this 
study: East Asia, Central Asia, the Mediterranean, Africa, Russia (including Central East, Caucasus, and northeastern Russia), North America, and Tibet. Because of its species richness and endemism, the QTP, Tibet is regarded as an area separated from the East Asian floristic region [13].

\section{Results}

\subsection{Phylogenetic Analyses}

3.1.1. 4-Gene Combined Analysis. The 4-gene combined dataset included 38 samples and 3099 bps; 496 variable characters were parsimony-uninformative and 421 were parsimony-informative. ML analysis resulted in three optimum trees, topologically almost equivalent; one of them is shown in Figure 1. Bootstrap support from PAUP and Bayesian posterior probability are labeled on the nodes in Figure 1.

Thermopsideae and Ammopiptanthus, respectively, formed a monophyletic group with high support, near $100 \%$ bootstrap (BT) and posterior probability values (PP). Piptanthus did not form a monophyletic group, since $P$. nepalense was placed outside of the genus (Figure 1). Even though the samples of Thermopsis came only from China (Figure 1), the results show that section Thermopsis sensu Sa et al. [28] can apparently be divided into two clades (Figure 1).

3.1.2. ITS Analysis. The ITS BEAST implementation yielded a phylogenetic tree and dating chronogram; see Figure 2. This topology of tree is in rough agreement with that of the previous ITS tree [14] and our 4-gene tree (Figure 1). It indicates that Ammopiptanthus and Thermopsideae are monophyletic groups, respectively. Importantly, this chronogram has a temporal evolutionary significance for the Thermopsideae, Podalyrieae, Crotalarieae, Genisteae, and so forth.

In contrast with previous phylogenies, especially Wang et al. [14], this ITS tree places Ammopiptanthus within Thermopsideae rather than outside of the tribe, and this is the same as in our 4-gene tree (Figure 1). The topological structure of the four tribes of core genistoides is also somewhat different from previous studies [19]; Thermopsideae is related to the cluster of Genisteae and Podalyrieae, while Crotalarieae is more isolated.

3.1.3. Estimating Divergence Times. Using seven fossil genera as constraints and outgroups, for 107 species and ITS dataset, the estimated root age of the four tribes of core genistoides was ca. 54.43 Ma and that of Thermopsideae was ca. 28.81 Ma, as presented in Figure 2. The estimated crown ages of the four tribes range from later Eocene $39.45 \mathrm{Ma}$ (Crotalarieae) to Miocene 11.89 Ma (Podalyrieae).

Within Thermopsideae, five genera are well monophyletic, respectively, with credible crown and stem ages excluding Thermopsis. Ammopiptanthus has stem age ca. 28.81 Ma, namely, crown age of Thermopsideae. In order to discuss the origin and evolution of taxa, a geological scale was appended to the BEAST diagram in Figure 2.
3.1.4. Biogeographic S-DIVA. Reconstruction of ancestral areas with S-DIVA (Figure 2) suggested that the ancestral distribution area of core genistoides is Africa (A) and that of Thermopsideae is possibly Central Asia (C) and that Ammopiptanthus is directly derived from Thermopsideae. Extant taxa of North America and the QTP are shown to be dispersals from Central Asia; several events of dispersal and vicariance are illustrated in Figure 2. The most distinct dispersal for the core genistoides is from Africa to Central Asia. From the QTP, a dispersal was westward via the Himalayas to the Mediterranean for the genus Anagyris, and dispersal and adaptive radiation to East Asia and Central Asia. The eastward line is via the Bering Strait to North America (Figures 2 and 3).

\section{Discussion}

4.1. Systematics of Thermopsideae. In the previous ITS phylogenetic tree [14], the five genera of Thermopsideae formed a well resolved monophyly, except for the fact that Ammopiptanthus fell outside of Thermopsideae due to the nesting of a few species of Sophora. In addition, diversification into East Asian and North American groups is observed in Thermopsis. From our 4-gene combined (Figure 1) and ITS trees (Figure 2), the monophyly of Thermopsideae and Ammopiptanthus is confirmed once more, and Ammopiptanthus is entirely included within Thermopsideae with high confidence support. Consequently, our enhanced species sampling and 4-gene tree (Figure 1) yield a distinct result compared with Wang et al. [14], mainly, that Thermopsideae is monophyletic, since the three Sophora species ( $S$. davidii, S. flavescens, and S. microphylla) are out of the tribe; two phylogenetic clades are recognized, where the previous tree only had one (see Figure 1 of Wang et al. [14]; our ITS tree also has one clade see Figure 2). This probably will be useful for the revision of classification $[28,51,52]$, especially for section Thermopsis sensu Sa et al. [28], of which most species occur in Asia. In addition, the previous taxonomic opinion of Ammopiptanthus being morphologically related to Piptanthus $[26,53]$ should be considered as reflecting a convergence, since our results (Figures 1 and 2) illustrate that they are separated in the tree. Vuralia has only one species $V$. turcica (Kit Tan et al.) and has a narrowed distribution (marshy side of Aksehir in Turkey) Uysal et al. [15], even though it had not been joined into the present dataset of Thermopsideae; however, together with Thermopsis chinensis and Th. fabacea, all are shown to be included into North America clade node 9 (Figure 2) [15].

4.2. Age and Distribution Pattern of Thermopsideae. The age of Thermopsideae has been estimated several times by the molecular dating approach. On the basis of fossil data, the genistoides crown node was constrained at $56.42 \pm 0.2 \mathrm{Ma}$. Lavin et al. [22] dated Thermopsideae to ca. 26.5 Ma, but only three species were sampled, that is, Piptanthus nepalense, Baptisia australis, and Thermopsis rhombifolia. This node of the genistoides is placed at ca. $54.43 \mathrm{Ma}$ (Figure 2), near this fossil constraint, confirming the validity of our dating. 


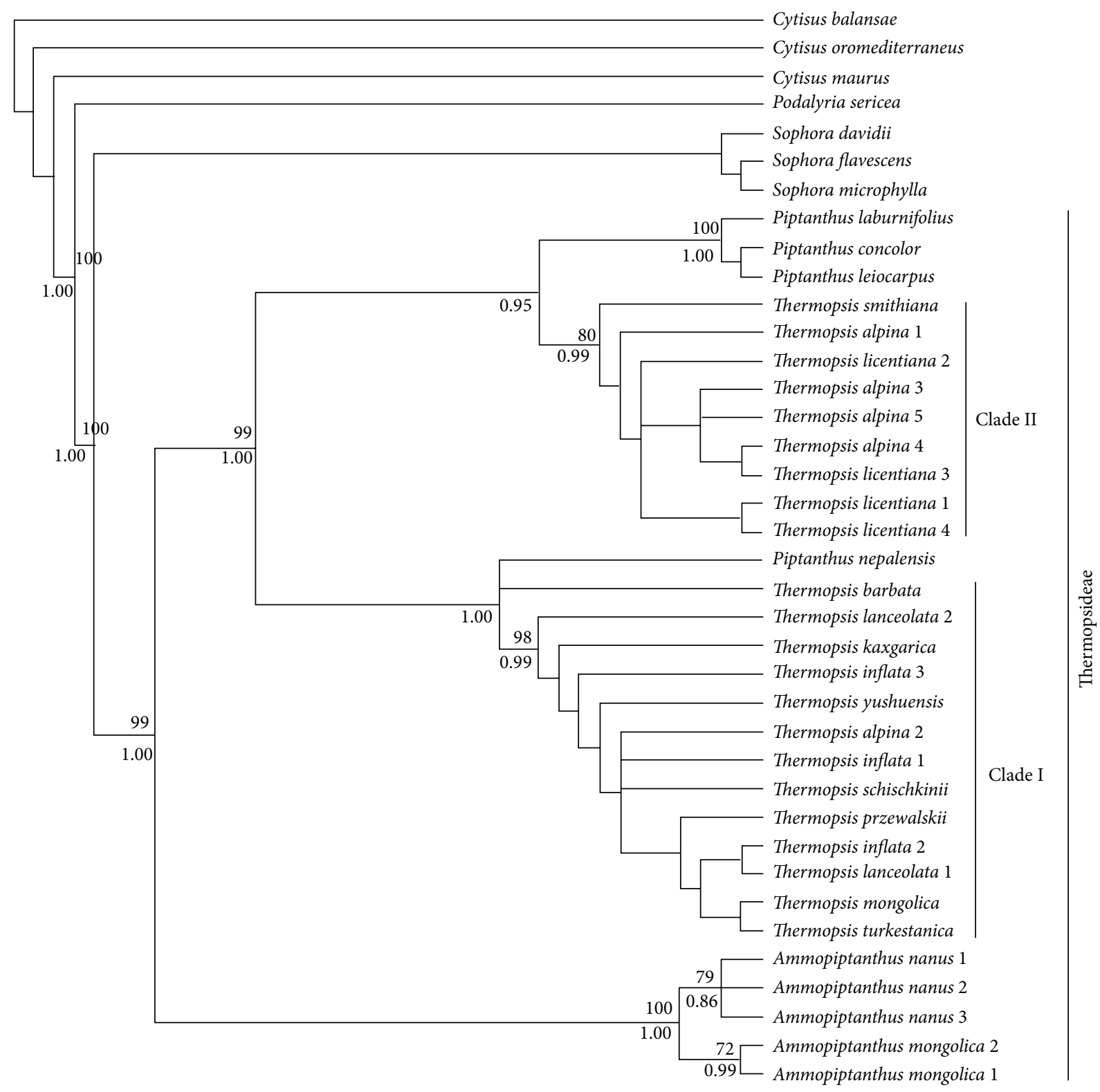

Figure 1: Phylogenetic tree resulted from maximum likelihood analysis of the combined dataset of 4 genes (ITS, $t r n \mathrm{~L}-\mathrm{F}, p s b \mathrm{~A}-\mathrm{trn \textrm {H }}$, and rps16). Bootstrap support values $>50 \%$ above branches and posterior probability support $>0.5$ below branches are indicated.

To estimate the age of Anagyris, Ortega-Olivencia and Catalán [12] employed numerous samples of the two species A. foetida and $A$. latifolia and added three other species in the tribe. Their results indicated that an estimated age of Thermopsideae was $27.2 \pm 4.1 \mathrm{Ma}$ and of Anagyris was $8.2 \pm 4.5 \mathrm{Ma}$. The present paper dates Thermopsideae to ca. $28.81 \mathrm{Ma}$, which approaches the dates from previous studies by Lavin et al. [22] and Ortega-Olivencia and Catalán [12]. Therefore, the middle Oligocene ca. 28.81 Ma should be treated as the diversification age of the tribe.

Along with the significant global climate cooling and increased aridity from Eocene to Oligocene, seven distinctive biomes have been recognized for the Oligocene (38 24 Ma) [54]. At ca. $30 \mathrm{Ma}$, one of seven is the warm/cool temperate biome, with a wide band of broadleaved evergreen and deciduous woodland throughout central Eurasia and North America. This biome in its northernmost part just covers the distribution range of Thermopsideae. These woodlands and forests replaced the dominantly evergreen paratropical rainforest of the middle Paleocene and much of the Eocene [54]. Therefore, we can determine that the original accompanying vegetation of Thermopsideae was woodlands and forest, with broadleaved evergreen and deciduous plants. From the Oligocene ca. $30 \mathrm{Ma}$ to middle-to-late Miocene, shrinkage of the Paratethys played an important role in causing transformation of the Central Asian climate from an oceanic to a continental condition [55]. As Hrbek and Meyer [56] have reviewed, the closing of the sea near 


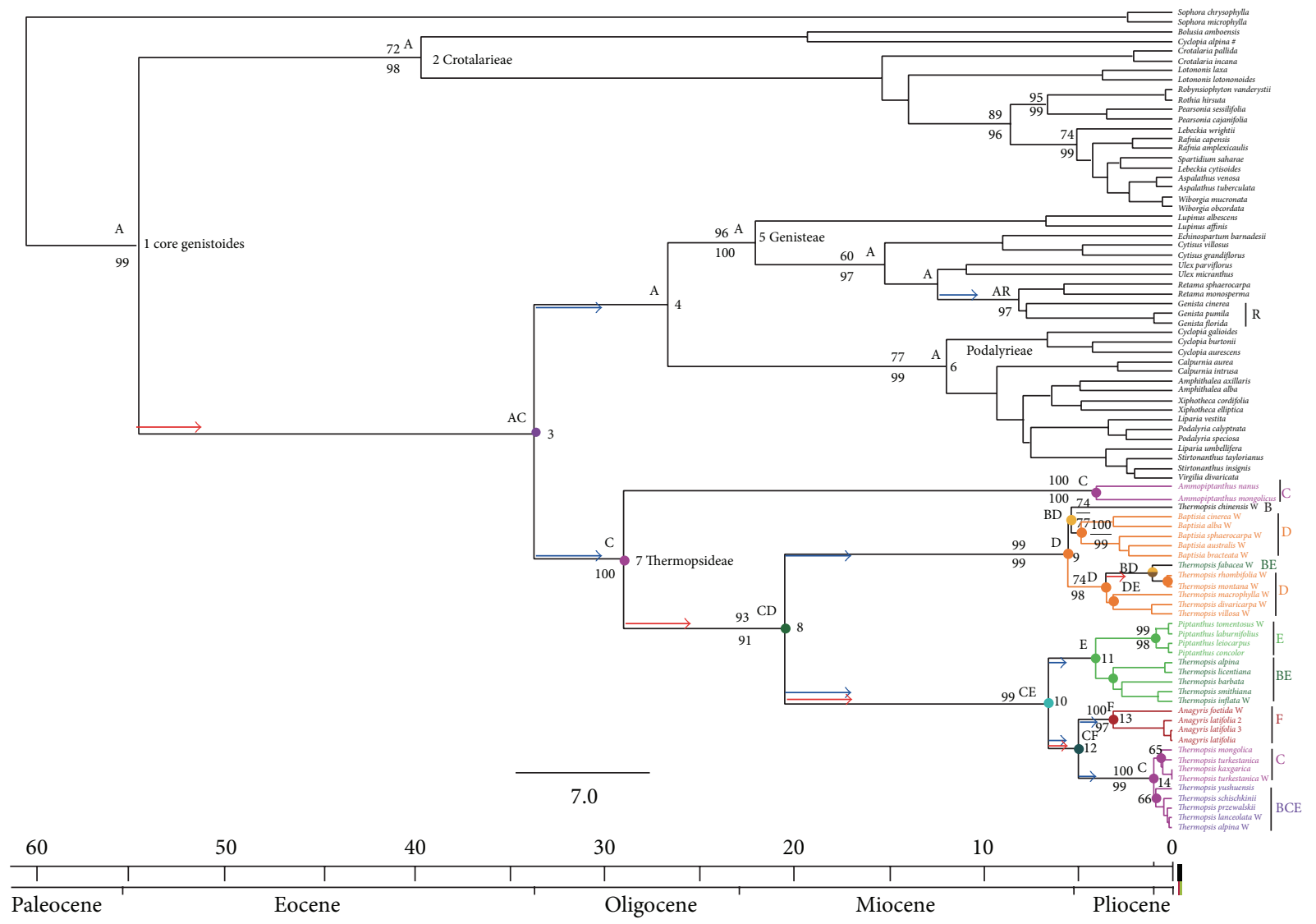

$\begin{array}{ll}\text { A: Africa } & \text { E: Tibet } \\ \text { B: East Asia } & \text { F: Mediterranean } \\ \text { C: Central Asia } & \text { R: Russia } \\ \begin{array}{l}\text { D: North America } \\ \longrightarrow \text { Dispersal resulting in range expansion } \\ \longrightarrow \text { Vicariance by cladogenesis }\end{array}\end{array}$

FIGURE 2: Chronogram of relaxed Bayesian BEAST on the basis of the ITS dataset. Estimated times (Ma) with 95\% HPD credibility intervals at concerned nodes were $1: 54.43$ (53.04-58.85), $2: 39.45$ (16.98-54.54), 3:33.47, $4: 26.51$ (13.59-42.87), 5:21.91 (7.09-23.65), 6:11.89 (4.7815.64), $7: 28.81$ (10.95-41.02), $8: 20.32$ (6.9-22.98), 9:5.48 (2.99-10.81), $10: 6.5$ (3.38-11.11), 11:4, $12: 4.9$ (1.6-6.89), 13:3.08 (0.26-3.2), and $14: 0.97(0.46-2.8)$. Bootstrap support values $>50 \%$ above branches and posterior probability values $>0.5$ below branches are indicated. "W" behind species name means species with the sequence data come from GenBank produced by Wang et al. [14]. S-DIVA optimal reconstruction of hypothesized ancestral areas at nodes and 10 dispersals with vertical line on branches are illustrated.

the Oligocene/Miocene boundary had a major impact on the distribution of organism diversity. Therefore, origin and diversification of the Thermopsideae at ca. $30 \mathrm{Ma}$ could therefore have been driven by the closing of the Paratethys, which resulted in a series of changes of environmental and ecological factors and profoundly affected the evolution of the tribe.

The Oligocene environment in Kazakhstan, with broadleaved forest and swamps, was indicated to be a wet climate [57]. However, the Paleogene floristics of northwestern and central China evidenced by fossil data was dry and subtropical [58]. During the Oligocene, the climate of middle China is speculated to have been an arid/semiarid belt [59]. Therefore, climate in Oligocene Central Asia should have changed from western wet (relic locations of Paratethys shrinkage) in Kazakhstan to eastern dry in northwestern China. These wet environments and climates of western parts of Central Asia most likely fit the emergence of the ancestor of Ammopiptanthus and Thermopsideae, with a broad-leaved forest and a wet to arid climate.

Therefore, from these perspectives of time and place of origin, paleovegetation, and paleoclimate, we can confirm a balanced Oligocene Central Asian origin of Thermopsideae.

4.3. Central Asian Origin and Diversifications among Central Asia, the QTP, and North America. In terms of our inferences of dispersal and vicariance in Thermopsideae (Figures 2 and 3), we can speculate that, after origination in Central Asia, most of its broadleaved evergreen and deciduous ancestors probably soon became extinct. 


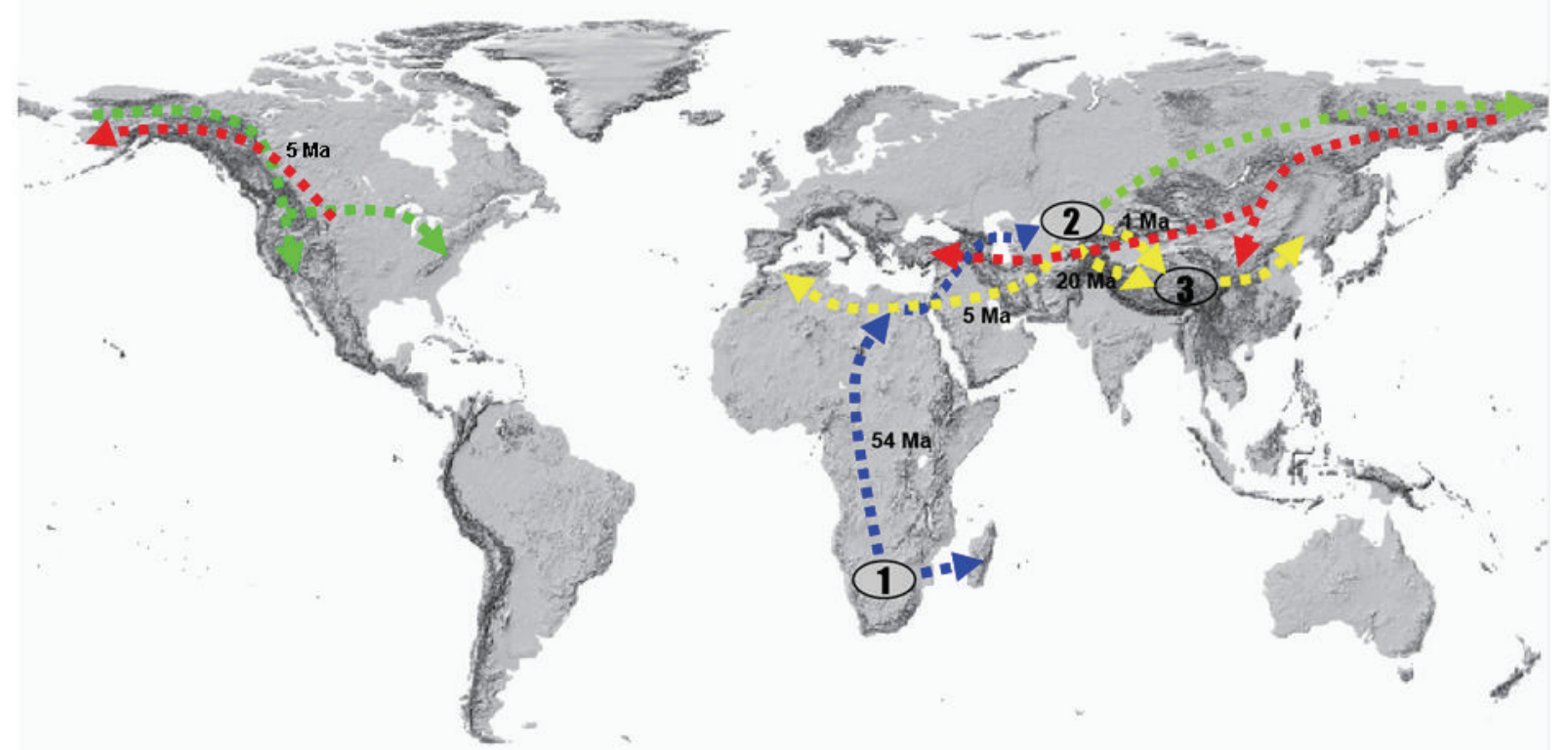

FIGURE 3: Scheme of dispersal routes from the biogeographical S-DIVA analysis, Figure 2. The blue dashed line indicates the origin center of core genistoides from Africa (elliptic 1), arriving in Central Asia (elliptic 2), which was the place of origin of the Thermopsideae; then there was a dispersal to North America. Routes are shown by green dashed lines. From Central Asia (elliptic 2), a dispersal westward via the Caucasus to the Mediterranean with genus Anagyris and dispersal and adaptive radiation to QTP (elliptic 3), from QTP to North China, are shown by yellow dashed lines. Dispersal from North America at about late Miocene eastward to East Asia and Mediterranean is shown by red lines.

Only a few survived, a case being Ammopiptanthus, which evolved from the ancestor of Thermopsideae (Figure 2). From the Central Asian ancestor, Thermopsideae had a dispersal to North America at ca. 28.81 Ma and to the QTP at ca. 20.32 Ma (Figures 2 and 3).

As mentioned above, shrinkage of the Paratethys starting from the Oligocene [55] was a dynamic influence for Thermopsideae and most likely also drove the dispersal to North America (dispersal from node 7 Figures 2 and 3). The diversification age between Central Asia and QTP of ca. 20.32 Ma implies a response to QTP uplift and extension as a geological event. QTP uplift is presumed to have initiated very early but had a major phase near the Oligocene-Miocene boundary when loess deposition began and strengthened thereafter. The first phase (Gangdese motion ca. $40 \mathrm{Ma}, 45 \sim$ $38 \mathrm{Ma}$ ) is characterized by the Indian plate subducting under the Eurasian plate, resulting in the rise of the Gangdise Mountains. High altitude conifers became abundant in the QTP starting at $38 \mathrm{Ma}$ [60]. The second phase (Himalayan motion ca. $21 \mathrm{Ma}, 25 \sim 17 \mathrm{Ma}$ ) is characterized by westward withdrawal of the Paratethys Sea and aridification of interior Asia. The rise or expansion of the QTP became sufficient for the initiation of dust deposition due to the Asian winter monsoon $[59,61,62]$. The third phase, uplift of northern and eastern parts of the QTP at many intervals during the late Neogene to Pleistocene [63-65] is correlated with appearance of ocean upwelling connected to development of the Asian summer monsoons. A particularly intense geologic uplift during this period was recorded in parts of the northernmost QTP at ca. 3.6 Ma $[63,66-68]$, which was accompanied by the intensification of monsoons to present levels.
These events strikingly influenced the ecology and environment of the QTP and adjacent regions, especially northern China. These ecological and environmental settings, consequently, can hold temporally the dispersal from Central Asia (see Figure 2, node 8) into the QTP.

The QTP and adjacent regions possess many endemic species in Thermopsideae (nodes 11,14 in Figure 2); these areas are shown by the analysis to be related mechanistically to Central Asia. A vicariance between the QTP and Central Asia is estimated at ca. $6.5 \mathrm{Ma}$ (node 10, Figure 2), whereas those species of the QTP, North China, and Central Asia (with BCE in Figure 2) are shown to come from the Central Asian ancestor node 14 (Figure 2) at ca. 0.97 Ma. Therefore, Central Asia shows a remarkable relation to the origin of Thermopsideae in temporal-spatial dimensions, in other words, evolution of Thermopsideae in Central Asia, was coupling with the multiple stages of uplift of the QTP since Cenozoic, which significantly affected the paleoenvironment, paleogeography, and paleoclimate in QTP and Central Asia. To explain evolutionary process of Thermopylae using uplift is reasonable. For instance, divergence of Piptanthus and other taxa in the QTP and North China (node 11 in Figure 2) is dated to ca. $4 \mathrm{Ma}$, during the third phase (intensive northern QTP uplift ca. 3.6 Ma). Piptanthus is estimated to be young, with a diversification age of ca. $0.85 \mathrm{Ma}$, which falls into the period of QTP maximum iceosphere (cryosphere) during the third phase of uplift $[66,68]$. Many people have discussed the East Asia-North America disjunction in regard to Thermopsis [14, 28, 51, 52, 69]. Yuan et al. [69-71] and Peng and Yuan [51] considered Thermopsis section Archithemopsis, C. J. Chen, R. Sa, and P. C. Li, to be occurring in Sino-Japanese 
regions, as the primitive group in the genus. Sa et al. [28] concluded that Thermopsis originated from the Sino-Japanese flora and then dispersed to North America via the Bering Strait. However, our analysis shows the ancestor of North American species to have come from Central Asia (node 8 in Figure 2) rather than East Asia and that the East Asia clade also on the whole evolved in Central Asia, which is different from previous hypotheses. In addition, a new genus Vuralia is erected from Thermopsis and related to North American node in the ITS phylogenetic tree [15], whereas Thermopsis chinensis and Th. fabacea (Figure 2) are also included in North American node; therefore, these three species in Eurasia can be regarded as the dispersals from North America and recent event in Pliocene-Pleistocene from North America crown root $5 \mathrm{Ma}$, as shown in Figures 2 and 3.

Meanwhile, our estimated diversification age of the Eurasia (Central Asia)-North America disjunction within Thermopsis is ca. $20.32 \mathrm{Ma}$ (node 8 in Figure 2). This early Miocene time is similar to that of most other genera showing East Asia-North America disjunctions, for example, Cercis ca. 15.41 Ma, Torreya ca. 16.7 Ma [72], Cornus 13.1 Ma [73], Calycanthus $16 \mathrm{Ma}$ [74], Epimedium-Vancouveria 9.7 Ma [75], and Hamamelis 7.7-7.1 Ma [76], but is different from Kelloggia with 5.42 Ma [77] and Phryma 5.23-3.68 [78]. As mentioned above, another diversification between Eurasia-North America disjunction which originates from North America at ca. 5 Ma Pliocene-Pleistocene (node 9, Figure 2) resembles Kelloggia and Phryma.

From Central Asia, a western dispersal route via the Caucasus arriving at the Mediterranean, is illustrated with Anagyris in Figures 2 and 3. Our dating of Anagyris is $3.08 \mathrm{Ma}$, which is different from the suggested age of $8.2 \pm 4.5 \mathrm{Ma}$ [12]. The Anagyris estimate of Ortega-Olivencia and Catalán [12] probably lacks denser sampling from Thermopsideae, since only 5-6 species were selected in total. In general, sufficient samples are necessary in dating. Vuvalia, another Mediterranean genus that belongs to the North America clade (node 9 in Figure 2), as well as Thermopsis chinensis and Th. fabacea, probably dispersed from North America in Pliocene-Pleistocene, since our estimated crown age of North America clade node 9 is about $5 \mathrm{Ma}$; see Figures 2 and 3.

4.4. Origin and Geographic Diversification of Ammopiptanthus. In view of the unique evergreen broadleaf habit of Ammopiptanthus in the desert region of northwestern China and Kyrgyzstan, many people have speculated that Ammopiptanthus is a relict of the evergreen broadleaf forest of this region from the Tertiary period $[14,26-29,79,80]$. The two species form an obvious disjunction pattern, A. mongolicus distributed in western Inner Mongolia and the south Gobi desert and A. nanus in the western Tianshan Mts. restricted to the borders between China and Kyrgyzstan [29]. Both species of Ammopiptanthus are diploid [81]. Genetic diversity from ISSR analysis [29] indicated that differentiation of the two species was significant. In view of its high genetic diversity, a vicariance possibly resulted from the fragmentation of the ancestor range.
From the present analysis (Figure 2), Ammopiptanthus is shown to be directly derived from the common ancestor of Thermopsideae, and its divergence time is estimated at ca. 28.81 Ma of middle Oligocene. As mentioned above, during this period, the climate was cooling and increasing in aridity and the vegetation was broadleaved evergreen and deciduous woodland. Therefore, Ammopiptanthus spatiotemporally should be speculated to be a relict survivor of the evergreen broadleaf forest at the Tertiary Oligocene.

Much evidence indicates that $\mathrm{CO}_{2}$ decline promoted the origin of $\mathrm{C}_{4}$ photosynthesis in grasses in the middle Oligocene ca. $30 \mathrm{Ma}$ [82-84]. Similar to $\mathrm{C}_{4}$ grass plants, emergence of Ammopiptanthus just falls into this period, and since it favors cold and arid climates in an arid region, it can be regarded as a plant case of response to $\mathrm{CO}_{2}$ decline.

The vicariance and fragmentation of the two Ammopiptanthus species dated to ca. 3.88 lead us to link these events to the time label 3.6 Ma of QTP intense uplift and consequently to Asian interior land aridification $[66,68,85]$. This is the same as the speciation of some species in Caragana [86] and Phyllolobium [87]. The vicariance and fragmentation of the two Ammopiptanthus species also likely corresponded to the low $\mathrm{pCO}_{2}$ and cold and arid climate that resulted from glacial intensification at late Pliocene times ( 3.3 to $2.4 \mathrm{Ma}$ ) (another time label is at middle Miocene $\sim 14$ to $10 \mathrm{Ma}$ ) [88].

4.5. Attribute of Madrean-Tethyan Disjunction of Thermopsideae. The Madrean-Tethyan disjunction was proposed by Axelrod [89], as reviewed recently by Wen and IckertBond [90], which hypothesized a nearly continuous belt of Madrean-Tethyan dry broadleaf evergreen sclerophyllous vegetation stretching from western North America to Central Asia in the early Tertiary (from Eocene to late Oligocene) at low latitudes. The former Madrean-Tethyan belt, in fact, falls into the succulent biome locating on the two sides of the Tethys in the Tertiary flora and vegetation, one of four biomes of the legume distribution pattern [21]. The representatives of taxa forming a distinctive disjunction in Thermopsideae are Thermopsis section Thermia and Baptisia in North America and Thermopsis sections excluding section Thermia and Piptanthus in Eurasia, mainly in the QTP and its adjacent regions and Ammopiptanthus in Central Asia and Anagyris in the Mediterranean. Clearly, Thermopsideae presents a Madrean-Tethyan disjunction. From the temporal dimension, our dating of Thermopsideae to Oligocene ca. 28.81 Ma, is just consistent with Axelrod [89] time range of early Tertiary Oligocene. This is different from the ages of origin of Madrean-Tethyan disjunctions (see review of Wen and Ickert-Bond [90]), for instance, Platanus orientalis-P. racemosa s.l. (Platanaceae) ca. 20.5-21.9 Ma [91]; Juniperus was at $43.66 \mathrm{Ma}$ [92]. Since Thermopsideae is illustrated to be derived from Central Asia, the evolutionary pattern of this tribe would be migration from Eurasia to North America via the Bering Strait. Moreover, types of Thermopsideae, except for members of Thermopsis and Baptisia, are perennial herbs producing rhizomes. The rest of these taxa, especially Ammopiptanthus, are shrubby and likely to be relicts of the Tertiary dry broadleaf evergreen sclerophyllous vegetation [89]. This, in fact, provides a relict status of dry broadleaf 
evergreen sclerophyllous vegetation of Madrean-Tethyan disjunction. Therefore, from perspectives of distribution, dated age, and vegetation of Thermopsideae, it fits as a good case of Madrean-Tethyan disjunction.

4.6. African Origin and Dispersal of Core Genistoides. The socalled core genistoides are defined on the basis of molecular phylogeny $[1,3-5,16-19]$. This clade has four tribes taxonomically [19], namely, Crotalarieae, Podalyrieae, Genisteae, and Thermopsideae. Except for Thermopsideae, the tribes occur mainly in Africa, and only a few species expand to the Mediterranean, southern Europe, the Middle East, the Caucasus, and Russia [6-8].

Schrire et al. [21] stated that the derived genistoides, including Crotalarieae, Podalyrieae, and Genisteae, have their basal branching elements in warm temperate southern Africa, an ancestral crown in the southern warm temperate biome [22]. From there, they would have migrated northwards through montane tropical Africa to the Mediterranean and Macaronesian regions and sequentially to the New World, or have secondarily invaded the tropics.

Our molecular dating and S-DIVA results (Figures 2 and 3 ) indicate that the core genistoides originated from Africa, probably warm temperate southern Africa as mentioned above [21], from Eocene to Oligocene ca. 54.43-33.47 Ma (Nodes 1,3). The four tribes not only dispersed to the Mediterranean, West Asia, the Caucasus, northwestern Russia, Central Asia, East Asia, and North America, but also continuously diversified in Africa in situ until middle Miocene ca. $12 \mathrm{Ma}$, which is fundamentally due to the diversification of the three tribes Crotalarieae, Podalyrieae, and Genisteae in that continent (Figure 2). The exact place of origin of these three tribes will probably become less ambiguous due to discovery of fossil records and increased taxon sampling and sequencing and so forth. However, an African origin is affirmed; furthermore, the biome warm temperate southern Africa, sensu Schrire et al. [21], is accepted here. This also illuminates the origin of Thermopsideae.

\section{Conflict of Interests}

The authors declare that there is no conflict of interests regarding the publication of this paper.

\section{Acknowledgments}

Thanks are to Dr. Yong-Ming Yuan and Dr. Heng-Chang Wang for their valuable comment and suggestion to the manuscript, to Dr. Rodrigo Duno de Stefano and anonymous referee for their critical, constructive, and helpful comment and suggestions, and to Professor Peter F. Stadler for his careful corrections to manuscript. This study was financially supported by National Natural Science Foundation of China (no. 41271070), China National Key Basic Research Program (2014CB54201) and Xinjiang Institute of Ecology and Geography, CAS.

\section{References}

[1] M. D. Crisp, S. Gilmore, and B. Van Wyk, "Molecular phylogeny of the genistoid tribes of papilionoid leguminosae," in Advances in Legume Systematics, Part 9, P. S. Herendeen and A. Bruneau, Eds., pp. 249-276, Royal Botanic Gardens, Kew, Richmond, UK, 2000.

[2] R. T. Pennington, M. Lavin, H. Ireland, B. Klitgaard, J. Preston, and J.-M. Hu, "Phylogenetic relationships of basal papilionoid legumes based upon sequences of the chloroplast trnL intron," Systematic Botany, vol. 26, no. 3, pp. 537-556, 2001.

[3] A. Ainouche, R. J. Bayer, P. Cubas, and M. T. Misset, "Phylogenetic relationships within tribe Genisteae (Papilionoideae) with special reference to genus Ulex," in Advances in Legume Systematics. Part 10: Higher Level Systematics, B. B. Klitgaard and A. Bruneau, Eds., pp. 239-252, Royal Botanic Gardens, Kew, UK, 2003.

[4] M. F. Wojciechowski, "Reconstructing the phylogeny of legumes (Leguminosae): an early 21st century perspective," in Advances in Legume Systematics, Part 10: Higher Level Systemat$i c s$, B. B. Klitgaard and A. Bruneau, Eds., pp. 5-35, Royal Botanic Garden, Kew, Richmond, UK, 2003.

[5] M. F. Wojciechowski, M. Lavin, and M. J. Sanderson, "A phylogeny of legumes (Leguminosae) based on analysis of the plastid matK gene resolves many well-supported subclades within the family," The American Journal of Botany, vol. 91, no. 11, pp. 1846-1862, 2004.

[6] J. M. Lock, "Thermopsideae," in Legumes of the World, G. Lewis, B. Schrire, B. Mackinder, and M. Lock, Eds., pp. 263-265, Royal Botanic Gardens, Surrey, UK, 2005.

[7] R. M. Polhill and B. E. van Wyk, "Genisteae," in Legumes of the World, G. Lewis, B. Schrire, B. Mackinder, and M. Lock, Eds., pp. 283-297, Royal Botanic Gardens, Kew, UK, 2005.

[8] B. E. Van Wyk, "Podalyrieae, Crotalarieae," in Legumes of the World, G. Lewis, B. Schrire, B. Mackinder, and M. Lock, Eds., pp. 267-282, Royal Botanic Gardens, Surrey, UK, 2005.

[9] B. L. Turner, “Thermopsideae," in Advances in Legume Systematics, R. M. Polhill and P. H. Raven, Eds., vol. 1, pp. 403-407, Royal Botanic Gardens, Kew, UK, 1981.

[10] M. F. Wojciechowski, "The origin and phylogenetic relationships of the Californian chaparral "paleoendemic" Pickeringia (Leguminosae)," Systematic Botany, vol. 38, no. 1, pp. 132-142, 2013.

[11] K. Browicz, "Geographic distribution of some shrubsfrom the family Leguminosae in southwestern Asia," in Arboretum Kornickie, Rocznik XXXII, pp. 5-30, 1978.

[12] A. Ortega-Olivencia and P. Catalán, "Systematics and evolutionary history of the circum-Mediterranean genus Anagyris L. (Fabaceae) based on morphological and molecular data," Taxon, vol. 58, no. 4, pp. 1290-1306, 2009.

[13] C. Y. Wu and S. G. Wu, A Proposal for a New Floristic Kingdom (Realm): The E. Asiatic Kingdom, Its Delineation and Character, CHEP \& Springer, Beijing, China, 1999.

[14] H. C. Wang, H. Sun, J. A. Compton, and J. B. Yang, "A phylogeny of Thermopsideae (Leguminosae: Papilionoideae) inferred from nuclear ribosomal internal transcribed spacer (ITS) sequences," Botanical Journal of the Linnean Society, vol. 151, no. 3, pp. 365-373, 2006.

[15] T. Uysal, K. Ertuğrul, and M. Bozkurt, "A new genus segregated from Thermopsis (Fabaceae: Papilionoideae): Vuralia," Plant Systematics and Evolution, vol. 300, no. 7, pp. 1627-1637, 2014. 
[16] T. Kajita, H. Ohashi, Y. Tateishi, C. D. Bailey, and J. J. Doyle, "rbcL and legume phylogeny, with particular reference to Phaseoleae, Millettieae, and allies," Systematic Botany, vol. 26, no. 3, pp. 515-536, 2001.

[17] A. Bruneau, M. Mercure, G. P. Lewis, and P. S. Herendeen, "Phylogenetic patterns and diversification in the caesalpinioid legumes," Botany, vol. 86, no. 7, pp. 697-718, 2008.

[18] M. A. Bello, A. Bruneau, F. Forest, and J. A. Hawkins, "Elusive relationships within order fabales: phylogenetic analyses using matK and rbcl sequence data," Systematic Botany, vol. 34, no. 1, pp. 102-114, 2009.

[19] G. Lewis, B. Schrire, B. Mackinder, and M. Lock, Legumes of the World, Royal Botanic Gardens, Kew, Richmond, UK, 2005.

[20] P. S. Herendeen, W. L. Crepet, and D. L. Dilche, "The fossil history of the Leguminosae: phylogenetic and biogeographic implications," in Advances in Legume Systematics, Part 4, P. S. Herendeen and D. L. Dilcher, Eds., pp. 303-316, Royal BotanicGardens, Kew, Richmond, UK, 1992.

[21] B. D. Schrire, G. P. Lewis, and M. Lavin, "Biogeography of the Leguminosae," in Legumes of the World, G. P. Lewis, B. D. Schrire, B. MacKinder, and M. Lock, Eds., pp. 21-54, Kew Publishing, 2005.

[22] M. Lavin, P. S. Herendeen, and M. F. Wojciechowski, "Evolutionary rates analysis of leguminosae implicates a rapid diversification of lineages during the Tertiary," Systematic Biology, vol. 54, no. 4, pp. 575-594, 2005.

[23] P. H. Raven and D. I. Axelrod, "Angiosperm biogeography and past continental movements," Annals of the Missouri Botanical Garden, vol. 61, no. 3, pp. 539-673, 1974.

[24] R. M. Polhill and P. H. Raven, "Papilionoideae," in Advances in Legume Systematics, Part 1, R. M. Polhill and P. H. Raven, Eds., pp. 191-208, Royal Botanic Gardens, Kew, UK, 1981.

[25] L. Xie and Y. Yang, "Miocene origin of the characteristic broadleaved evergreen shrub Ammopiptanthus (leguminosae) in the desert flora of eastern central Asia," International Journal of Plant Sciences, vol. 173, no. 8, pp. 944-955, 2012.

[26] P. C. Li and Z. C. Ni, "The formation and evolution of Fabaceae in Xizang," Acta Phytotaxonomica Sinica, vol. 20, pp. 142-154, 1982.

[27] C. Y. Wu and H. S. Wang, Plant Geography, Science Press, Beijing, China, 1983, (Chinese).

[28] R. Sa, J. C. Chen, and P. C. Li, "The phytogeographical studies of Thermopsis (Leguminosae)," Acta Phytotaxonomica Sinica, vol. 38, pp. 148-166, 2000.

[29] X.-J. Ge, Y. Yu, Y.-M. Yuan, H.-W. Huang, and C. Yan, "Genetic diversity and geographic differentiation in endangered Ammopiptanthus (Leguminosae) populations in desert regions of northwest China as revealed by ISSR analysis," Annals of Botany, vol. 95, no. 5, pp. 843-851, 2005.

[30] J. Doyle and J. L. Doyle, "Genomic plant DNA preparation from fresh tissue-CTAB method," Phytochemical Bulletin, vol. 19, pp. 11-15, 1987.

[31] Y. Kang, M.-L. Zhang, and Z.-D. Chen, "A preliminary phylogenetic study of the subgenus Pogonophace (Astragalus) in China based on ITS sequence Data," Acta Botanica Sinica, vol. 45, no. 2, pp. 140-145, 2003.

[32] P. Taberlet, L. Gielly, G. Pautou, and J. Bouvet, "Universal primers for amplification of three non-coding regions of chloroplast DNA," Plant Molecular Biology, vol. 17, no. 5, pp. 1105-1109, 1991.
[33] T. Sang, D. J. Crawford, and T. F. Stuessy, "Chloroplast DNA phylogeny, reticulate evolution, and biogeography of Paeonia (Paeoniaceae)," The American Journal of Botany, vol. 84, no. 8, pp. 1120-1136, 1997.

[34] J. A. Tate and B. B. Simpson, "Paraphyly of Tarasa (Malvaceae) and diverse origins of the polyploid species," Systematic Botany, vol. 28, no. 4, pp. 723-737, 2003.

[35] B. Oxelman, M. Lidén, and D. Berglund, "Chloroplast rps16 intron phylogeny of the tribe Sileneae (Caryophyllaceae)," Plant Systematics and Evolution, vol. 206, no. 1-4, pp. 393-410, 1997.

[36] L. A. Johnson and D. E. Soltis, "Phylogenetic inference in Saxifragaceae sensu stricto and Gilia (Polemoniaceae) using matK sequences," Annals of the Missouri Botanical Garden, vol. 82, no. 2, pp. 149-175, 1995.

[37] J. D. Thompson, T. J. Gibson, F. Plewniak, F. Jeanmougin, and D. G. Higgins, "The CLUSTAL_X windows interface: flexible strategies for multiple sequence alignment aided by quality analysis tools," Nucleic Acids Research, vol. 25, pp. 4876-4882, 1997.

[38] T. A. Hall, "BioEdit: a user-friendly biological sequence alignment editor and analysis program for Windows 95/98/NT," Nucleic Acids Symposium Series, vol. 41, pp. 95-98, 1999.

[39] J. S. Farris, M. Källersjö, A. G. Kluge, and C. Bult, “Testing significance of incongruence," Cladistics, vol. 10, pp. 315-319, 1994.

[40] D. L. Swofford, 'PAUP*,' Phylogenetic Analysis Using Parsimony, Version 4.0b10, Sinauer, Sunderland, Mass, USA, 2002.

[41] D. Posada and K. A. Crandall, "Modeltest: testing the model of DNA substitution," Bioinformatics, vol. 14, no. 9, pp. 817-818, 1998.

[42] J. R. Tao, Z. K. Zhou, and Y. S. Liu, The Evolution of the Late Cretaceous-Cenozonic Floras in China, Science Press, Beijing, China, 2000 (Chinese).

[43] Institute of Botany, Nanjing Institute of Geology and Palaeontology (IB \& NIGP), and Academia Sinica, Chinese Plant Fossils, Volume 3: Neogene Floras, Academic Press, Beijing, China, 1978.

[44] S. S. Renner, "Relaxed molecular clocks for dating historical plant dispersal events," Trends in Plant Science, vol. 10, no. 11, pp. 550-558, 2005.

[45] J. J. Welch and L. Bromham, "Molecular dating when rates vary," Trends in Ecology and Evolution, vol. 20, no. 6, pp. 320-327, 2005.

[46] A. J. Drummond and A. Rambaut, "BEAST: bayesian evolutionary analysis by sampling trees," BMC Evolutionary Biology, vol. 7, no. 1, article 214, 2007.

[47] F. Ronquist, "Dispersal-vicariance analysis: a new approach to the quantification of historical biogeography," Systematic Biology, vol. 46, no. 1, pp. 195-203, 1997.

[48] F. Ronquist, DIVA Version 1.1, (ftp.uu.se orftp.systbot.uu.se), Uppsala Univeristy, Uppsala, Sweden, 1996.

[49] J. A. A. Nylander, U. Olsson, P. Alström, and I. Sanmartín, "Accounting for phylogenetic uncertainty in biogeography: a Bayesian approach to dispersal-vicariance analysis of the thrushes (Aves: Turdus)," Systematic Biology, vol. 57, no. 2, pp. 257-268, 2008.

[50] Y. Yu, A. J. Harris, and X. He, "S-DIVA (Statistical DispersalVicariance Analysis): a tool for inferring biogeographic histories," Molecular Phylogenetics and Evolution, vol. 56, no. 2, pp. 848-850, 2010.

[51] Z. X. Peng and Y. M. Yuan, "Systematic revision on Thermopsideae (Leguminosae) of China," Acta Botanica BorealiOccidentalia Sinica, vol. 12, pp. 158-166, 1992. 
[52] C. J. Chen, M. G. Mendenhall, and B. L. Turner, "Taxonomy of Thermopsis (Fabaceae) in North America," Annals of the Missouri Botanical Garden, vol. 81, no. 4, pp. 714-742, 1994.

[53] S. H. Cheng, "Ammopiptanthus Cheng f., a new genus of Leguminosae from Central Asia," Botanicheskii Zhurnal, vol. 44, pp. 1381-1386, 1959.

[54] K. J. Willis and J. C. McElwain, The Evolution of Plants, Oxford University Press, New York, NY, USA, 2002.

[55] G. Ramstein, F. Fluteau, J. Besse, and S. Joussaume, "Effect of orogeny, plate motion and land-sea distribution on Eurasian climate change over the past 30 million years," Nature, vol. 386, no. 6627, pp. 788-795, 1997.

[56] T. Hrbek and A. Meyer, "Closing of the Tethys Sea and the phylogeny of Eurasian killifishes (Cyprinodontiformes: Cyprinodontidae)," Journal of Evolutionary Biology, vol. 16, no. 1, pp. 17-36, 2003.

[57] V. A. Zubakov and I. I. Borzenkova, Global Palaeoclimate of the Late Cenozoic, vol. 12 of Developments in Palaeontology and Stratigraphy, Elsevier, Amsterdam, The Netherlands, 1990.

[58] J. R. Tao, "The Tertiary vegetation and flora and floristic regions in China," Acta Phytotaxomica Sinica, vol. 31, pp. 25-43, 1992.

[59] Z. T. Guo, B. Sun, Z. S. Zhang et al., "A major reorganization of Asian climate by the early Miocene," Climate of the Past, vol. 4, no. 3, pp. 153-174, 2008.

[60] G. Dupont-Nivet, C. Hoom, and M. Konert, "Tibetan uplift prior to the Eocene-Oligocene climate transition: evidence from pollen analysis of the Xining Basin," Geology, vol. 36, no. 12, pp. 987-990, 2008.

[61] Z. T. Guo, W. F. Ruddiman, Q. Z. Hao et al., "Onset of Asian desertification by $22 \mathrm{Myr}$ ago inferred from loess deposits in China," Nature, vol. 416, no. 6877, pp. 159-163, 2002.

[62] J. L. Pei, Z. M. Sun, X. S. Wang et al., "Evidence for Tibetan Plateau uplift in Qaidam basin before Eocene-Oligocene boundary and its climatic implications," Journal of Earth Science, vol. 20, no. 2, pp. 430-437, 2009.

[63] Z. S. An, J. E. Kutzbach, W. L. Prell, and S. C. Porter, "Evolution of Asian monsoons and phased uplift of the Himalaya-Tibetan plateau since Late Miocene times," Nature, vol. 411, no. 6833, pp. 62-66, 2001.

[64] X. M. Wang, B. Y. Wang, Z. X. Qiu et al., "Danghe area (western Gansu, China) biostratigraphy and implications for depositional history and tectonics of northern Tibetan Plateau," Earth and Planetary Science Letters, vol. 208, no. 3-4, pp. 253269, 2003.

[65] G. J. Li, T. Pettke, and J. Chen, "Increasing Nd isotopic ratio of Asian dust indicates progressive uplift of the north Tibetan Plateau since the middle Miocene," Geology, vol. 39, no. 3, pp. 199-202, 2011.

[66] J. J. Li and X. M. Fang, "Research on the uplift of the QinghaiXizang Plateau and environmental changes," Chinese Science Bulletin, vol. 43, pp. 1569-1574, 1998.

[67] X. Fang, W. Zhang, Q. Meng et al., "High-resolution magnetostratigraphy of the Neogene Huaitoutala section in the eastern Qaidam Basin on the NE Tibetan Plateau, Qinghai Province, China and its implication on tectonic uplift of the NE Tibetan Plateau," Earth and Planetary Science Letters, vol. 258, no. 1-2, pp. 293-306, 2007.

[68] Y. F. Shi, M. C. Tang, and Y. Z. Ma, “The relation of second rising in Qinghai-Xizang Plateau and Asia Monsoon," Sciences in China D, vol. 28, pp. 263-271, 1998.
[69] Y. M. Yuan and C. J. Chen, "Anatomical evidence for phylogeny of the tribe Thermopsideae (Leguminosae)," Journal of Lanzhou University (Natural Sciences), vol. 29, pp. 97-104, 1993.

[70] Y. M. Yuan, Z. X. Peng, and C. J. Chen, “The systematical and ecological significance of anatomical characters of leaves in the tribe Thermopsideae (Leguminosae)," Acta Botanica Sinica, vol. 33, pp. 840-847, 1991.

[71] Y. M. Yuan and Z. X. Peng, "Pollen morphology and its systematic significance of the tribe Thermopsideae (Leguminosae) from China," Acta Botanica Boreali-Occidentalia Sinica, vol. 27, pp. 84-95, 1991.

[72] M. J. Donoghue, C. D. Bell, and J. Li, "Phylogenetic patterns in Northern Hemisphere plant geography," International Journal of Plant Sciences, vol. 162, pp. S41-S52, 2001.

[73] Q. Y. Xiang, D. E. Soltis, and P. S. Soltis, "Phylogenetic relationships of Cornaceae and close relatives inferred from mat $K$ and $r b c L$ sequences," American Journal of Botany, vol. 85, no. 2, pp. 285-297, 1998.

[74] S. L. Zhou, S. S. Renner, and J. Wen, "Molecular phylogeny and intra- and intercontinental biogeography of Calycanthaceae," Molecular Phylogenetics and Evolution, vol. 39, no. 1, pp. 1-15, 2006.

[75] M.-L. Zhang, C. H. Uhink, and J. W. Kadereit, "Phylogeny and biogeography of Epimedium/Vancouveria (Berberidaceae): Western North American-East Asian disjunctions, the origin of European mountain plant taxa, and East Asian species diversity," Systematic Botany, vol. 32, no. 1, pp. 81-92, 2007.

[76] L. Xie, T.-S. Yi, R. Li, D. Z. Li, and J. Wen, "Evolution and biogeographic diversification of the witch-hazel genus (Hamamelis L., Hamamelidaceae) in the Northern Hemisphere," Molecular Phylogenetics and Evolution, vol. 56, no. 2, pp. 675-689, 2010.

[77] Z.-L. Nie, J. Wen, H. Sun, and B. Bartholomew, "Monophyly of Kelloggia Torrey ex Benth. (Rubiaceae) and evolution of its intercontinental disjunction between western North America and eastern Asia," American Journal of Botany, vol. 92, no. 4, pp. 642-652, 2005.

[78] Z.-L. Nie, H. Sun, P. M. Beardsley, R. G. Olmstead, and J. Wen, "Evolution of biogeographic disjunction between eastern Asia and eastern North America in Phryma (Phrymaceae)," The American Journal of Botany, vol. 93, no. 9, pp. 1343-1356, 2006.

[79] J. Q. Liu, M. X. Qiu, K. Yang, and Q. H. Shi, "Studies on the plant community of Ammopiptanthus mongolicus," Journal of Desert Research, vol. 15, pp. 109-115, 1995.

[80] B. Y. Geng, J. R. Tao, and G. P. Xie, "Early Tertiary fossil plants and paleoclimate of Lanzhou Basin," Acta Phytaxonomica Sinica, vol. 39, no. 2, pp. 105-115, 2001.

[81] B. R. Pan and S. P. Huang, "Cytological study of the genus Ammopipthanthus," Acta Botanica Sinica, vol. 35, pp. 314-317, 1993.

[82] R. F. Sage, “The evolution of $\mathrm{C}_{4}$ photosynthesis," New Phytologist, vol. 161, no. 2, pp. 341-370, 2004.

[83] P.-A. Christin, G. Besnard, E. Samaritani et al., "Oligocene $\mathrm{CO}_{2}$ decline promoted $\mathrm{C}_{4}$ photosynthesis in grasses," Current Biology, vol. 18, no. 1, pp. 37-43, 2008.

[84] A. Vicentini, J. C. Barber, S. S. Aliscioni, L. M. Giussani, and E. A. Kellogg, "The age of the grasses and clusters of origins of $\mathrm{C}_{4}$ photosynthesis," Global Change Biology, vol. 14, no. 12, pp. 2963-2977, 2008.

[85] Y. F. Shi, J. J. Li, B. Y. Li et al., "Uplift of the Qinghai-Xizang (Tibetan) Plateau and east asia environmental change during late Cenozoic," Acta Geographica Sinica, vol. 54, no. 1, pp. 1021, 1999. 
[86] M.-L. Zhang and P. W. Fritsch, "Evolutionary response of Caragana (Fabaceae) to Qinghai-Tibetan Plateau uplift and Asian interior aridification," Plant Systematics and Evolution, vol. 288, no. 3-4, pp. 191-199, 2010.

[87] M.-L. Zhang, Y. Kang, Y. Zhong, and S. C. Sanderson, "Intense uplift of the Qinghai-Tibetan Plateau triggered rapid diversification of Phyllolobium (Leguminosae) in the Late Cenozoic," Plant Ecology and Diversity, vol. 5, no. 4, pp. 491-499, 2012.

[88] A. K. Tripati, C. D. Roberts, and R. A. Eagle, "Coupling of $\mathrm{CO}_{2}$ and Ice sheet stability over major climate transitions of the last 20 million years," Science, vol. 326, no. 5958, pp. 1394-1397, 2009.

[89] D. I. Axelrod, "Evolution and biogeography of MadreanTethyan sclerophyll vegetation," Annals of the Missouri Botanical Garden, vol. 62, no. 2, pp. 280-334, 1975.

[90] J. Wen and S. M. Ickert-Bond, "Evolution of the MadreanTethyan disjunctions and the North and South American amphitropical disjunctions in plants," Journal of Systematics and Evolution, vol. 47, no. 5, pp. 331-348, 2009.

[91] Y. Feng, S.-H. Oh, and P. S. Manos, "Phylogeny and historical biogeography of the genus Platanus as inferred from nuclear and chloroplast DNA," Systematic Botany, vol. 30, no. 4, pp. 786799, 2005.

[92] K. S. Mao, G. Hao, J. Q. Liu, R. P. Adams, and R. I. Milne, "Diversification and biogeography of Juniperus (Cupressaceae): variable diversification rates and multiple intercontinental dispersals," New Phytologist, vol. 188, no. 1, pp. 254-272, 2010. 

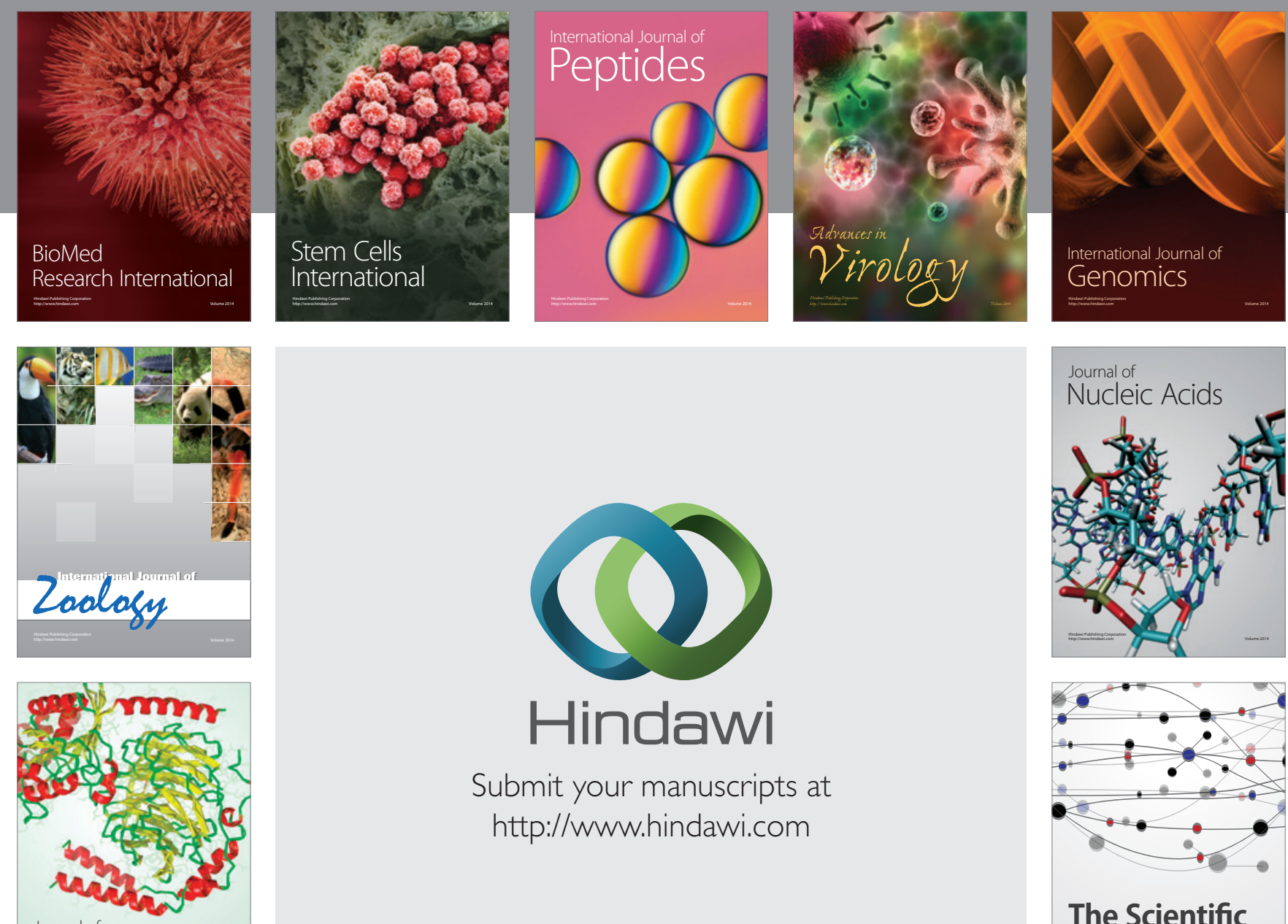

Submit your manuscripts at

http://www.hindawi.com

Journal of
Signal Transduction
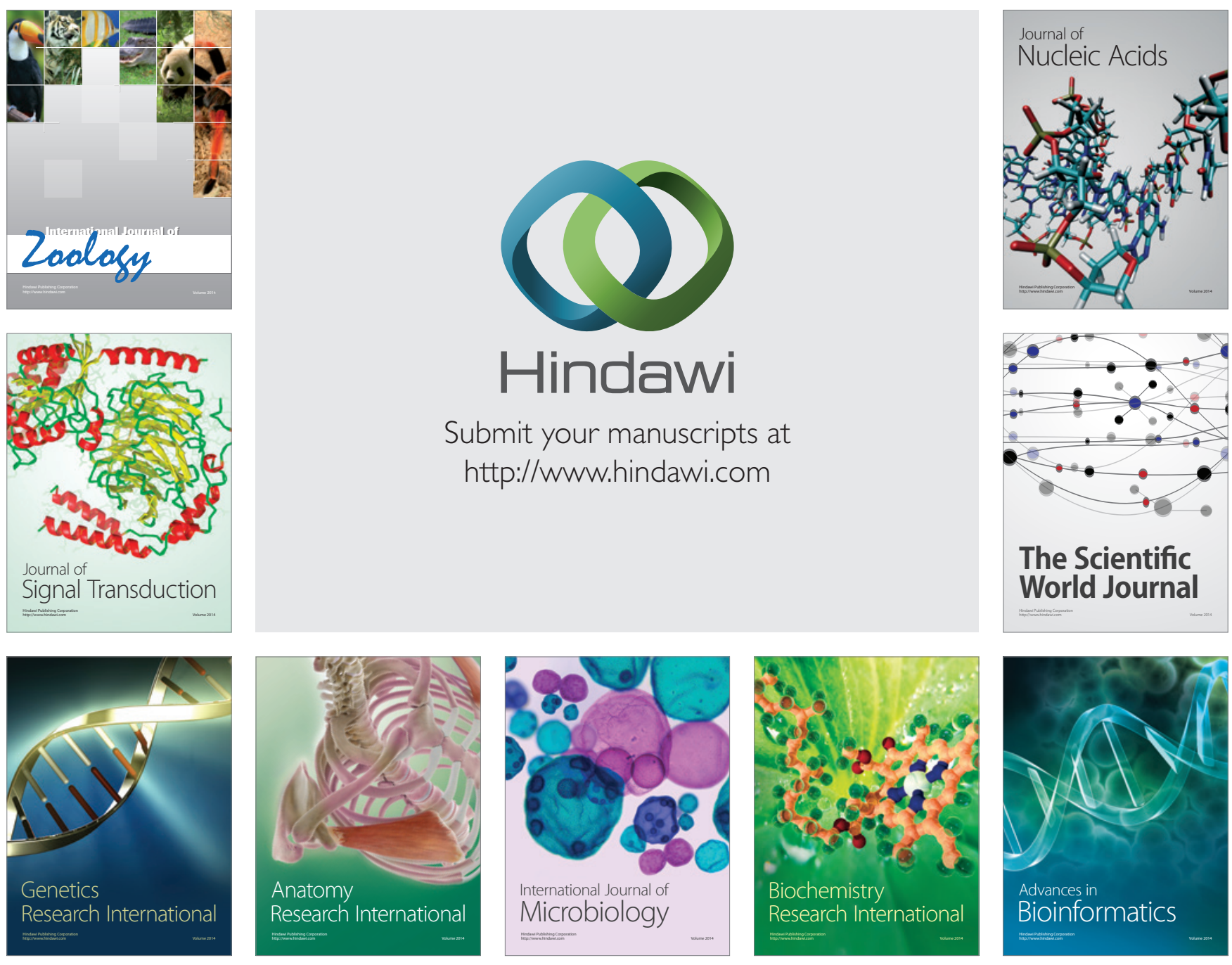

The Scientific World Journal
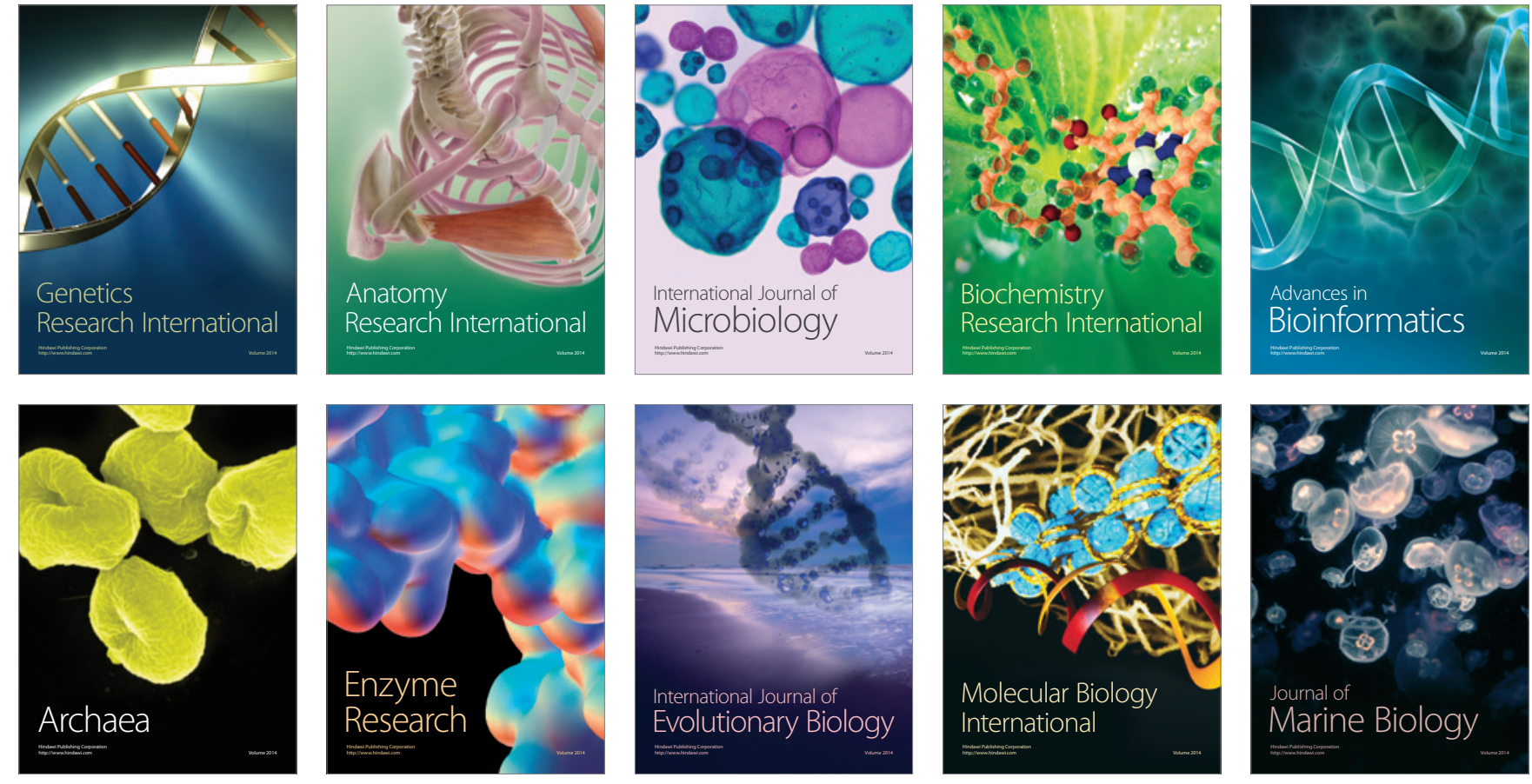